\title{
Metaphor and Translation Strategies in News English
}

\author{
Li Hongjuan \\ Tianjin Maritime College
}

Keywords: News English; Metaphor; Translation; Skills

\begin{abstract}
As a figure of speech, metaphor is more vivid and flexible than simile, so metaphor can better express the theme in news English and enhance readers' cognition, rendering great help in creating characteristic news release with intense infection. In translating metaphors in news English, in order to retain the original information and accurately convey them to readers, special skills of translating metaphors are needed. This paper first analyzes the application of metaphors in news English and then analyzes and summarizes skills and strategies of translating metaphors.

Generally, news English refers to a more formal and standard English used for reporting English news in traditional media such as newspaper, radio and television. In addition to being public, interesting and concise as generally news language, news English often uses metaphors, which can make the news more interesting and the language more vivid as well as better express the author's thoughts and opinions implicitly. Different from general styles, the contents of news should be responsible for the public. Therefore, in translating news English, it is better to try to retain the original meaning and convey the metaphor. Mastering skills of translating metaphors is the only way to accurately translate news English.
\end{abstract}

\section{Metaphors in News English}

As a more subtle and tactful means of expressing language, metaphors can seek common points between two irrelevant things and build a link, which is consistent with metaphors in Chinese. According to Chinese customs, metaphor is used in the form of "A is B", different from simile, which is in the form of "A is like B". Thus, it can be seen that conjunctions between the metaphorical body and the metaphorical objects in metaphors show strong affirmative tone, making readers or audiences understand it more intuitively and vividly. It is the same with English, in which metaphors can make the language more powerful and direct. For example, "a milestone in bilateral ties” can be translated into “双边关系的里程碑”; “a cradle for terror” can be translated into “恐怖 主义的摇篮”; “armed to the teeth” can be translated into “武装到牙齿”; “a castle in the air” can be translated into “空中楼阁”; “chain reaction” can be translated into “连锁反应”; and "shadow cabinet” can be translated into “影子内阁”.

Metaphors in news English can be generally divided into conceptual metaphors and non-conceptual metaphors. Among them, conceptual metaphors refer to metaphors of a certain feature of certain things, and the source metaphorical text has the same meaning as the translated text. It is more easy to understand and translate conceptual metaphors. Although languages of different nations are subject to the influence of their respective culture and history to a great extent, the history of mankind is common, so from this perspective, it is easy to understand the concept of metaphor. Some natural phenomena exist objectively, so in both English-speaking countries and non-English speaking countries, there are common cognitions, which is the basis to generate conceptual metaphors. For instance, “a thunder of applause” can be translated into “雷鸣般的掌声”. As a natural phenomenon, the loudness of thunder is known to all readers, so it is easy to understand such metaphor. Another example, "a thunder from the blue" can be translated into “晴天 霹雾”; “raining tears” can be translated into “泪如雨下”. On the other hand, metaphorical thinks are derived from human production and life experience. Any nation will experience the same feelings pf life, such as illness, life and death, love and marriage. With the same emotional experience, people of all countries will have the same cognitions in metaphors, so it can be found that it is easy to understand many metaphors in news English. For example, "push the boat with the 
current" can be translated into “顺水推舟”, “to strike while the iron is hot" can be translated into “趁热打铁”, “rub salt into the wound” can be translated into “往伤口上撒盐”, “failure is the mother of success" can be translated into “失败是成功之母”, and “to fish in trouble water" can be translated into “浑水摸鱼”, etc.

From the perspective of understanding, non-conceptual metaphor causes certain difficulties to translators in translation, and it is far less intuitive and easy to be understood than conceptual metaphors. If the source language and translated language of conceptual metaphors have the same meaning intuitively, then they are irrelevant in non-conceptual metaphors. In order to describe a new thing or object with non-conceptual metaphor, it is necessary to establish an "informal contact" between two (categories of) things. Such contact reflects the structure of already known or familiar things onto new things, and it can also enrich writing language. The appearance of non-conceptual metaphor should be attributed to the cultural background of different languages, so English and Chinese often express the same meaning with different things. For instance, "a cat on the bricks" can be translated into “热锅上的蚂蚁”; “a black sheep” can be translated into “害群之马”, “lion in the way” can be translated into “拦路虎”, “donkey in a lions hid” can be translated into “狐假虎 威”, “apple of the eye” can be translated into “掌上明珠”, and “paint the lily” can be translated into “画蛇添足”, etc.

\section{Strategies of Translating Metaphors in News English}

Translation workers have exerted a lot of energy to study the translation of metaphors in news English and have summarized the several following translation strategies.

First, the strategy of "metaphor-metaphor". This strategy can be used when there are exactly corresponding or equivalent things in Chinese with the things described in English, so that not only the original cultural characteristics can be maintained, but the translated version can also be more interesting and easily understood. For example, there are such a metaphor: one is this has not happened, explains Mr. Anderson, is that the bosses of state-owned Chinese firms treat their jobs as stepping stones to higher political office. It can be translated like this: 安德森认为这种情况没有 发生的一个原因在于, 中国国有企业的领导们把他们的工作视为迈向更高层政治职务的垫脚 石。

Second, the strategy of "metaphor-simile". Some obvious feature words of simile can be added while this strategy is used so that it is easier to understand metaphors. Actually, metaphor and simile themselves share a lot of common points in that both of them can express the similarities between different things. Therefore, while translating metaphors in news English, similes in Chinese can be appropriately used to replace metaphors in the original text. Appropriately using simile words like “像”, “似的” and “如果” can be used in the translated version to make readers have a better understanding of metaphors. For example, there is a metaphor: The real problem is “city-killers"-things too small for existing surveys to see, but large enough to do serious damage. It can be translated into 真正的问题是类似“城市杀手”般的小行星，这种小行星用我们目前的手 段很难观测到，但它却能带来巨大破坏性。

Third, the strategy "metaphor-folk adage". If it is hard for readers to understand the translated version of metaphor, some folk adages can be added to further explain this metaphor instead of dropping the metaphors from the original texts because readers find it hard to understand, which will cause the lack of the expression effect. For instance, there is a metaphor: High fuel prices were mainly to blame but the EU's new carbon tax was the "nail in the coffin". It can be translated like this: 这其中的主要原因是燃料价格过高, 但欧盟新增的碳排放税才是棺材上的钉子一一致命 一击。

Fourth, "replacement" strategy, which uses the metaphorical targets in Chinese to replace the metaphorical objects, but both of them have similar meanings. Chinese readers and English readers have different cultural backgrounds, so different metaphorical targets can be used to express the same or similar meaning of the same concept. The lack of cultural background and cognitive 
thinking may cause Chinese readers to have misunderstanding of the metaphors after they are directly translated. At this time, "replacement" strategy can be used to translated the original metaphorical objects into Chinese objects that can be easily understood by Chinese readers. For example, It's a Cyclops stabbing itself in the eye. It cannot be translated into “刺自己的眼睛”, but should be translated into “搬起石头砸自己的脚”, which is more appropriate.

\section{Methods of Translating Metaphors in News English}

There are mainly four methods to translate metaphors in news English.

The first is literal translation, a commonly used, direct and standard translation habit in translation that can basically retain meaning of the original text. While translating metaphors, literal translation can translate the complete of metaphors into the translated version without adding other modifiers to change the original cultural elements and national colors. Literal translation does not mean mechanical translation, but to translate the metaphors more intuitively according to the originality principle. For example, the report is going to raise alarms that the economy is slipping into recession again. This sentence can be translated into “这份报告将敲响经济再次陷入衰退的 警钟”. Such translation is clear at the first glance and readers can also feel the vividness.

The second is free translation, which is usually regarded as the highest level of translation. When literal translation would destroy the original meaning or artistic conception of metaphor, making it hard for readers to understand and accept the meaning, free translation is required. Free translation can render better effect of flexibly and reasonably conveying the meaning. For example, in translating “red tape", if it is translated literally, “红色的带子”will be obtained, but it is very awkward. After understanding the cultural background of the United Kingdom, we can know that official documents in the U.K. are usually tied with red tapes, so in free translation, it can be translated into “繁文缛节” or “官僚主义作风”.

The third is amplification [1]. There are many expressions in English combined with national history and cultural background, which cannot be well-known to ordinary readers, so readers should bear the responsibility of amplification by properly adding the translated version so that it can be more easily understood by readers. For example, the sentence "Thus question has opened Pandora's Box” can be translated into “这个问题打开了潘多拉的盒子”. Although there is no problem to this translation, for those readers who do not know the Greek allusion Pandora's Box, they still do not know what is being said. Therefore, another sentence can be added to the translated version, so that this sentence can be translated into “这个问题打开了潘多拉的盒子，许多问题由此而生”. Such translation is clear to readers and they can easily accept it.

The last is transliteration, which is also commonly used. when an English metaphor has similar meaning with a certain expression in Chinese, but the translated Chinese metaphorical objects have several corresponding English metaphorical objects, readers may have derivation in understanding while reading. Thus, in order to remove this difficulty in understanding brought by cultural differences, transliteration can be used to translate the metaphor into a more acceptable metaphorical object. For instance, it was the first time that Mr. Clinton, who is facing the most severe political crisis of his career, picked the Pentagon as the backdrop for a major address. In this sentence, the original meaning of "backdrop" is "background", but it cannot be translated like this, so it should be translated into “挡箭牌”, i.e., “把五角大楼作为解决问题的挡箭牌”.

Speaking of skills of translating metaphors in news English, like translation of all forms of work, the principle of "faithfulness, expressiveness and elegance" should be followed. Based on this, reasonably using the above four translation methods can accurately and vividly translate metaphors in news English.

Actually, in order to appropriately and vividly metaphors in news English, translators should first accumulate a lot of knowledge about Western cultural background and traditional history, appropriately use the above translation strategies and skills and the combine their accumulated knowledge. Only in this way can they translate excellent news works. 


\section{References}

News Research, Dec 2015

[1] Kong Lifang. On Metaphors in News English and their Translation, [J]. News Research Guide, Journal of News Research, December 2015.

[2] LuZhengGuo, MAO Cui. Virtual reality technology in the application of computer maintenance course teaching research [J]. Journal of fujian computer, 2012, 11:193-194.

[3] RongJianTing. Virtual reality technology in the application of computer assembly and maintenance of teaching thinking [J]. Journal of secondary vocational education, 2012, 10, 35 and 36.

[4] zhang Ming, shu-ying wang, guo tao. Virtual reality technology in the application of computer professional practice teaching [J]. Journal of intelligence, 2011, 12:105.

[5] Tian zhen xie. Translation studies after the "cultural turn" - the cultural turn of translation studies in comparative literature significance $[\mathrm{J}]$. Journal of comparative literature in China. $2006(3)$ 